\title{
避難行動予測における図式解法の問題点と $\mathrm{EB}$ モデルの提案
}

\author{
$\mathrm{EB}$ モデル（伸縮ブロックモデル）による群衆流の解析 その 1
}

\section{はじめに}

近年，建築計画の避難上の安全性を評価するための避 難行動予測は，設計実務の場において極めて広く普及し てきた。ここで採用されている解法は，ほとんどが建築 防災計画指針 ${ }^{1}$ に示された方法（以下，指針法と略す） である。これはグラフを作図しながら解析を進める，図 式解法の一種であるが, 群衆の速度と密度の関係が十分 には反映されていない。

最近になってソ連の Predtechenskii と Milinskii に よる解法 (以下, PM 法と略す) が紹介された注!。こ れも図式解法であるが，群衆の密度と速度の関係を緻密 に取り上げて解析するものである。しかし，この解法に も群衆歩行として不自然な面が見られた。

これら二つの図式解法は，数式のみによる方法や大型 コンピュータを使用するものに比較すると，わかりやす く簡易な点で実用的である。また，このために，群衆歩 行特性の一部を省略する必要性も否定できない。しかし， これらの解法を検討すると，群衆流解析を研究する立場 としては見逃せない問題が残されていることがわかっ た。

\section{1. 研究目的と研究概要}

以上のような在来の群衆流解析法の問題点を明らかに し，速度と密度の関係を反映できる新しい簡易な解法を 提案することが本研究の目的である。

本報においてはまず，同一の例題を指針法と PM 法 とを用いて解析すると，両者の解析結果には大きな隔た りが現れることを示す。次にその原因と両解析法の問題 点を明らかにし，これを解決するために伸縮ブロックモ デル (Elastic Block Model, 以下, EBモデルと略す) を提案しこれを用いた解析結果を示す。

\section{2. 在来の図式解法の比較検討}

ここでは同一の例題を，指針法と PM 法によって解 析した過程, 解析結果の比較およびこれらの解析法の問 題点を明らかにする。

本研究の一部は, 1989 年度日本建築学会大会 (熊本, 10月) において 発表した。

*（株）竹中工務店東京本店設計部・工修 (1989 年 9 月 6 日原稿受理, 1989 年 12 月 19 日採用決定
正会員吉 田 克 之*

2.1 指針法と PM 法の概要と歩行特性值の共通化

（1） 在来の図式解法の概要

指針法は筆者が文献 5) で提案した図式解法を発展さ せたものであるが，用いている群衆の歩行特性值は戸川 喜久二博士（以下，戸川と略す）の研究6)に基づいてい る。その内容は避難時間と混雑状況を予測し，別途与え られる許容值と比較することにより，避難計画を評価す るものである。解析で作成する図は縦軸に累積人数を， 横軸に時間をとり，グラフのこう配が単位時間当たりの 人数を表す。設計実務の場での利用を考え，それまでの 数式のみによる解法より間違いなく，わかりやすく解析 できることを目的として考案された。わが国では 1981 年より超高層ビル等の申請手続きにおいて避難計算が必 要となったため,この手法が広く採用されており，適用 事例は 1989 年 7 月現在で 1,100 件を超えるものと推定 される注2)。

一方，PM 法は大規模な公共建築物における適正な 設計を目的として考案されたもので，その内容は指針法 と同様に群衆の通過時間や混雑状況を予測するものであ る。また，オーストリアの Kendik はこれを応用した研 究7)発表している。文献 2) によればソ連では 1930 年 代から群案流動の組織的な研究が行われており，図式解 法も 1940 年代後半に考案されていた。PM 法も図式解 放であるが，指針法と異なって縦軸に進行方向の距離を， 横軸に経過時間をとり，グラフのこう配は群衆の速度を 表す仕組みである。速度は別途用意された密度・速度・ 流動係数の関連数表 (以下, 数表と略す) から読る,取る。 数表には通路，開口部，階段 (昇降別) の 4 種があり， それぞれについて非常時, 平常時, 快適時の 3 種類の值 の組み合わせが用意されている。

（2）歩行特性値の共通化

これら二つの手法では，それぞれの群衆流動の観測に 基づく歩行特性值（速度, 密度, 流動係数）が採用され ているが，そのまま解析すると，その結果には解析手法 そのものの違いによる差のほかに，基礎データの違いに よる誤差が混入する。このため本研究では，以下のよう な考察を行い，両手法の本質を歪めない範囲での特性値 の共通化を図った。 


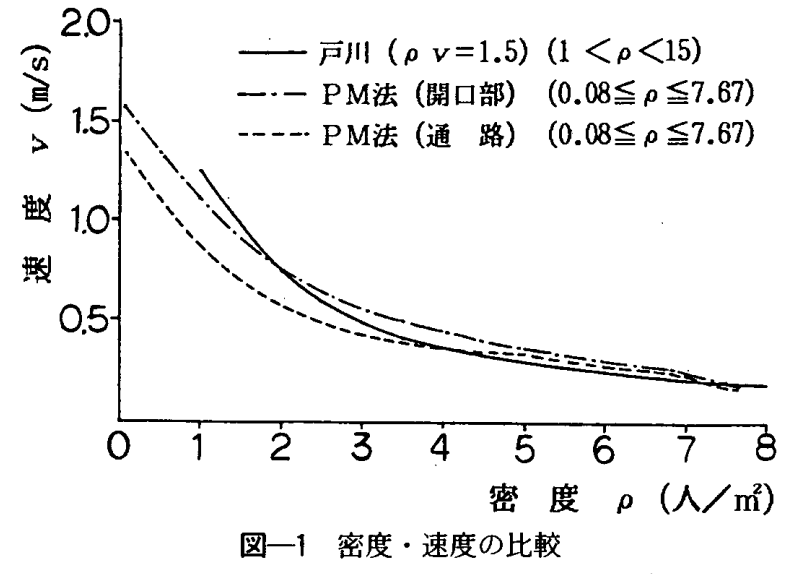

まず，集団の速度 $v$ と密度 $\rho$ の関係であるが，これ は流動係数 $N$ を用いて次式で定義される。

$$
N=\rho v
$$

ここで戸川は $1<\rho<15\left(人 / \mathrm{m}^{2}\right)$ の範囲において $N$ の値は一定であるとしているき3)。PM 法の数表におい ても速度, 密度, 流動係数の間には（1）式の関係が成 り立っているが, $N$ が一定ではなく, 速度と密度によっ て変動する点が戸川とは異なる。その違いを図一1で比 較すると，おおむ的密度 3 人 $/ \mathrm{m}^{2}$ 以下の場合には戸川 の值の方がやや速度が高いが，3人/ $\mathrm{m}^{2}$ 以上では近似 している。

自由歩行速度 $v_{m x}^{\text {i注4) }}$ は，指針法では廊下で $1.0 \mathrm{~m} / \mathrm{s}$, 密度の低い居室で $1.3 \mathrm{~m} / \mathrm{s}$ となっているが, $\mathrm{PM}$ 法の非 常時の值では, 水平通路で $1.35 \mathrm{~m} / \mathrm{s}$, 扉等のネックで $1.58 \mathrm{~m} / \mathrm{s}$ である。

また，歩行集団がネックによって滞留するときの最大 密度 $\rho_{m x}$ についても, 指針法では附室で 5 人 $/ \mathrm{m}^{2}$, 廊下 で 3.33 人 $/ \mathrm{m}^{2}, \mathrm{PM}$ 法では 7.36 人 $/ \mathrm{m}^{2}$ が数表の最大 值である。

両解析法には以上のような違いがあり，どの値を採用 すべきかについては意見が分かれるところである。しか し, これを追求することが本研究の主旨ではないので, ここでは $N$ については戸川の提案する 1.5 人 $/ \mathrm{m} \cdot \mathrm{s}$ に 固定し, 自由歩行速度 $v_{m x}$ についても, 戸川が示した

(1) 式の成り立つ範囲において $\rho$ を 1 人 $/ \mathrm{m}^{2}$ とした

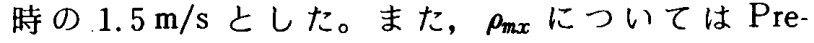
dtechenskii らの值に近い整数である 8 人 $/ \mathrm{m}^{2}$ を採用し た。また，PM 法では密度を床面積に対する，人の垂 直投影面積の比率 $\left(\mathrm{m}^{2} / \mathrm{m}^{2}\right)$, 流動係数を単位時間に通 過する集団の長さ (m/分) で表しているが，これも比 較を容易にするため，式を引用する場合には指針法と同 じ単位系に変換した。

また，指針法における滞留人数は，文献 1) ではネッ ク手前の待ち人数だけでなく, 通路を歩行中の人数を加 えた人数として定義されているが，本研究では指針法に おいても PM 法と同様に, ネック手前の待ち人数のみ

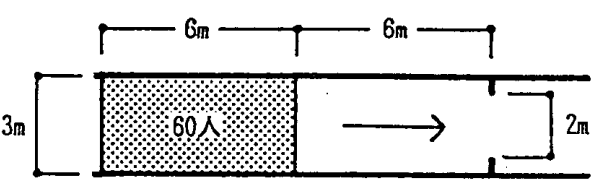

図一2 解析に用いた例題

を滞留人数とし，その占める部分を「滞留圈」と呼ぶこ とにした。

図一 2 は 60 人の集団が通路に停止した状態から右方 向へ進むものとし，前方には $2 \mathrm{~m}$ 幅のネックがあると した例題である。

\section{2 指針法による解析結果}

図一2 の例題を指針法で解いた結果を図一 3 に示す。 速度が $1.5 \mathrm{~m} / \mathrm{s}$ であるため, 先頭は歩行開始から 4 秒後, 末尾は 8 秒後にネックに到着する。また， $N=1.5$ 人 $\mathrm{m} \cdot \mathrm{s}$ より, 扉の通過容量は 3.0 人 $/ \mathrm{s}, .60$ 人全員が通過 するのに要する時間は 20 秒である。図一 3 においてグ ラフ(1)は歩行者のネックへの到着時間分布を, グラフ(2) はネック通過時間分布を，それぞれ表す。

滞留人数は到着と流出の差であるから，図上ではグラ フ(1)とグラフ(2)の差が滞留人数である。最大滞留人数 $P_{w m x}$ は, 歩行開始後 8 秒目に発生する。集団の人数を $P$ ，ネックの幅を $W_{n k}$, 集団先頭のネックへの到着を歩 行開始から $t_{t}$ 秒後, 末尾の到着を $t_{b}$ 秒後とすれば, $P_{w m x}$ は次式で定義されている。

$$
P_{w m x}=P-W_{n k} N\left(t_{b}-t_{t}\right)
$$

上式より $P_{w m x}=42$ 人を得る。

\subsection{PM 法による解析結果}

PM 法による解析結果を図一 4 に示す。図一4のグラ フ(1)と(2)は集団の末尾と先頭のそれぞれの歩行状況を表 す。両者のこう配は等しく, (1) 式において $N=1.5$, $\rho=60 / 18\left(人 / \mathrm{m}^{2}\right)$ とした場合の速度; $0.45 \mathrm{~m} / \mathrm{s}$ である。 先頭のネックへの到着時刻は図一 4 中の点 $\mathrm{A}$ で示され る。この時刻以降に, ネックの前に滞留圏が形成されて ゆくことになるが，その形成速度，すなわち滞留圈の末

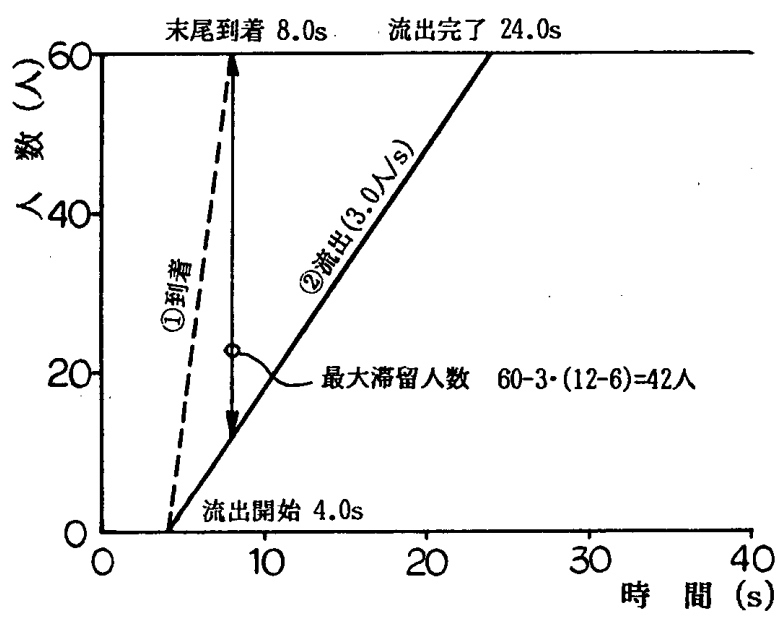

図一３指針法による解析結果 


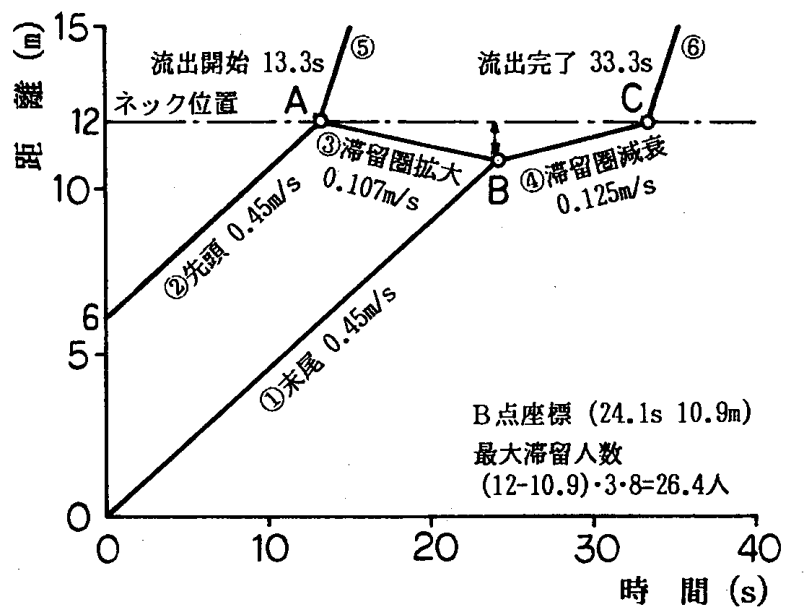

図一4 PM 法による解析結果

尾位置の速度 $v_{c}^{\prime}$ は次式で求める。

$$
v_{c}^{\prime}=\frac{N_{n k} \frac{W_{n k}}{W_{r w}}-N_{r w}}{\rho_{n k}-\rho_{r w}} .
$$

ここで $W$ は幅員 $(\mathrm{m}), \rho$ は密度 $\left(人 / \mathrm{m}^{2}\right)$ で, 添字 $r w, n k$ はそれぞれ通路とネックを示す。 $\rho_{n k}$ は滞留圈の 密度で, 人の密集した時の最大密度 $\rho_{m x}$ を用いる。本報 では前記共通化によって $N$ の值を一定としたため，（3） 式は次式に変換された。

$$
v_{c}^{\prime}=\frac{N\left(\frac{W_{n k}}{W_{r w}}-1\right)}{\rho_{m x}-\rho_{r w}}
$$

(4) 式に $\rho_{r w}$ に $60 / 18$ 人 $/ \mathrm{m}^{2}, W_{n k} に 2 \mathrm{~m}, W_{r w}$ に $3 \mathrm{~m}, N$ に 1.5 人 $/ \mathrm{m} \cdot \mathrm{s}$ を代入し, $v_{c}^{\prime}=-0.107$ を得た。 すなわち，A点よりこう配一0.107で引いたグラフ(3)が 滞留圈の形成状況であり，このグラフとグラフ(1)との交 点 $\mathrm{B}$ において最大滞留人数が求められる。図一 4 におい $\tau$, 原点からの歩行距離を $D$, 経過時間を $t$ とすると, グラフ(1)と(3)の式は以下のとおりである。

$$
\text { グラフ(1): } D=0.45 t
$$

グラフ(3) : $D=-0.107 t+13.43$

これを解いて B点の座標 $(21.4,10.9)$ を得た。さら に, 滞留圈の長さ $L_{w}=12-10.9=1.1 \mathrm{~m}$, 幅員 $W_{r w}=3$ $\mathrm{m}, \rho_{m x}=8$ 人 $/ \mathrm{m}^{2}$ から, 最大滞留人数 $P_{w m x}$ を次の式で 求めた。

$$
P_{w m x}=L_{w} W_{r w} \rho_{m x}=26.4
$$

また，PM 法によれば B 点以降の滞留圈の減衰，す なわち滞留の末尾の進行速度 $v_{c}$ は次式で定義されてい る。

$$
v_{c}=v_{n k} \frac{W_{n k}}{W_{r w}}
$$

上式において $v_{n k}$ は滞留圈の密度から決まる速度，す なわち (1) 式より 1.5/8 であることから， $v_{c}=0.125$ $(\mathrm{m} / \mathrm{s})$ を得た。したがって，B点を通るこう配 0.125 のグラフ(4)が滞留圏の诚衰状況であり,このグラフと
ネックの位置 $(D=12)$ との交点Cがネック通過完了時 刻である。グラフ(4)は $\mathrm{B}$ 点 $(21.4,10.9)$ を通り，その こう配が 0.125 であることから，その式は次式であるこ とがわかる。

$$
D=0.125 t+7.84
$$

また，これに $D=12 \mathrm{~m}$ を代入し，流出完了時刻 33.3 秒を得た。

PM 法ではネックを通過した集団の速度は, ネック 通過後の流動係数 $N_{3}$ を(10) 式で求め, 数表からこの 流動係数の值を示す速度を求めることとしているが, 本 報では $N$ を一定としたため，(10）式が矛盾を起こし, ネック通過後の速度を求めることができなかった。図一 4 ではネック通過後の速度を $v_{m x}$ としてグラフ(5)，(6)を 作図した。

$$
N_{3}=N_{n k} \frac{W_{n k}}{W_{r w}}
$$

\section{4 解析結果の比較之両解析法の問題点}

両者の解析結果（表一1）を比較すると，本質的には 同じ理論に基づいているにもかかわらず，大きな隔たり が見られた。この違いの存在はこれらの解法に問題があ ることを示唆するものである。ここでは両者の比較をし ながらその問題点をまとめた。

\section{(1) 時 間}

ネック通過所要時間は, 指針法では単に人数, 流動係 数，ネック幅から得られるのに対し，PM 法ではまず 滞留圈の拡大速度を求め, 次に滞留圈に対する末尾の到 着時刻を求め, 滞留圈の減衰速度を求め, これより通過 完了時刻を求めるという, 複雑な手続きが必要である。 このように計算手続きは異なっても，両解析法とも結果 は等しく 20 秒であった。これによっても, 両解析法と も本質的には同じ手法であることが確認できる。

次に, 流出開始時刻と流出完了時刻には大きな違いが 見られるが，これは指針法では集団の速度を $1.5 \mathrm{~m} / \mathrm{s}$ と

\begin{tabular}{|c|c|c|}
\hline 解析 項 目 & 指針法 & P M法 \\
\hline ネック手前の速度 & 1. $5 \mathrm{~m} / \mathrm{s}$ & $0.45 \mathrm{~m} / \mathrm{s}$ \\
\hline ネック流出開始 & 4. 0 秒 & 13. 3秒 \\
\hline ネック流出完了 & 24. 0秒 & 33. 3秒 \\
\hline ネック通過所要時間 & 20. 0 秒 & 20.0 秒 \\
\hline 最大滞留人数 & 42 . 0 人 & 26.4 人 \\
\hline 最大滞留時刻 & 10. 0 秒目 & 24. 1秒目 \\
\hline ネック通過後の速度 & 1. $5 \mathrm{~m} / \mathrm{s}$ & （不定） \\
\hline
\end{tabular}
しているのに対し，PM 法では $0.45 \mathrm{~m} / \mathrm{s}$ としているこ とが原因であることは明白である。両者の速度の違いは 3 倍以上の開きがあるが，これについてはどちらが正し いかというより，両者とも先頭から末尾までの，集団全 体が等しい速度で歩行することに問題があると考える。

表一1 両解析法による結果の比較 
集団の先頭付近には密度の低い部分があることは, Predtechenskii らも認めているところであり，また， 戸川の観察でも報告されている注5)。集団が自由歩行速 度で歩行できる時の密度を自由歩行密度 $\rho_{f r}$ と呼ぶとす ると, 集団の密度が $\rho_{s r}$ 以上の場合, 先頭が後続部分と 同じ低い速度で歩行するのは実態と比較して不自然であ る。この点で, 指針法の先頭速度は $v_{m x}$ としているこ とは是認できるが, 末尾も同じ速度で歩行するのは群衆 流を正しく反映しているとは言えない。一方，PM 法 では，末尾は密度に応じた速度であるが，先頭について も末尾の速度を採用していることは，実態を反映してい るとは言い難い。

実際の群衆流を観察すれば, 集団の先頭は速度が高く, これによって先頭から徐々に密度が低下し，歩行するに つれて次第に㹡散し，一人一人の速度も上昇してゆくこ とは明らかである。このような「集団の拡散」が，指針 法と PM 法で考慮されていないのは問題である。すな わち両解析法の結果の違いは, 集団の速度, 特に先頭之 末尾との速度差を考慮していないことに起因するもので あり，これを解決するには「集団の拡散」を考慮した解 析法が必要なことが明らかになった。

\section{(2) 滞留人数}

これについても指針法で 42 人, PM 法で 26 人と, 大きな開きが見られた。まます，指針法に対しては次の二 つの問題点が指摘できる。第 1 に, 指針法では集団末尾 が先頭と同じ速度で歩行するため, ネックへの到着が実 態より早くなり，これによって滞留人数が多めに見積も られることである。集団末尾の速度が低ければ図一 3 中 の到着グラフ(1)こう配はもっと緩くなり，滞留人数は 解析結果より少ないであろうことは容易に推察される。 第 2 の問題は，滞留圏の面積を無視している点である。 指針法で求めた滞留人数は, 到着と流出の差の人数であ るが，実際には滞留圏がネック手前の部分を占有するた め, 人は図上のネック到着より以前に滞留圏の末尾に到 着する。したがって，第 1 の問題指摘とは逆に，ここで は滞留人数は少なめに見積もられていると言える注6)。

このような指針法に対し，PM 法では（4）式によっ て滞留圈の拡大速度を定義し, 作図によって最大滞留圈 の長さを求め, 滞留面積と $\rho_{m x}$ から滞留人数を求めてい る。この式について検討してみると,これは到着時間分 布が一定，すなわち定常流の到着に対するものであり， この限りにおいて正しいことを確認したが, 集団が拡散 しながら到着する場合，すなわち非定常到着の場合には 成り立たない。また, 図一4の解析では先頭のネック到 着時間が遅いこともあり,この点でも結果の値は正しい とは言えない。

以上の考察結果より, 指針法と PM 法のいずれによっ ても正しい滞留圈の形成過程は求められないことが確か
められ，この点でも集団の拡散を取り込んだモデルが必 要なことが明らかとなった。

\section{EBモデル}

集団の拡散, すなわち当初の密度が拡散しながら速度 を上昇させてゆく現象で，もっとも顕著な例の一つに青 梅マラソンがある。これは歩行集団ではないが, 12,000 人が $9 \mathrm{~m}$ 幅の道路に $800 \mathrm{~m}$ にわたって停止した状態か ら, 一斉にスタートするもので, 先頭に近い部分以外は 混雑（平均密度 1.7 人 $/ \mathrm{m}^{2}$ ) のため, しばらくはスピー ドが出せず，最終ランナーがスタートラインを通過する までに 6 分かかると言われている主7)。先頭集団は招待 選手であり,一般参加の後続集団よの走る能力には,はっ きりとした差があるとしても, 混雑による速度低下も影 響していることは否定できない注8)。

このような集団の拡散, すなわち当初の密度が拡散し ながら速度を上昇させてゆく現象は, 横断歩道の信号待 ち群衆の歩行開始時などでも観察される。

また,このような集団の拡散が団体行動の障害となり, これを避けるために特別の工夫を必要亡することもあ る。例えば分列行進をする場合，いきなり歩行開始させ ると, 先頭亡末尾との速度差によって行列が次第に長く なってしまう。行列の長さを元に戻すには, 列の後半の 人々は駆け足をしなければならない。整然とした分列行 進をさせるために, 行進開始に先立ってあらかじめ足踏 みをさせたり, 歩行開始直後の先頭の速度を抑制する等 の工夫が現実に行われている住91。

また，たとえばデモ行進などの行列を見ていると，次 のような現象も観察できる。すなわち，集団が信号など で停止する時には, 先頭が停止しても後続部分は同時に は停止せず，前方の人に十分に接近，あるいは接触する まで歩行を続ける。このため, 密度の低かった集団が， 停止した時には高密度になる。そして，ふたたび歩行が 開始されると集団が徐々に拡散してゆくのである。

このように集団の拡散現象は，日常しばしば観察され るにもかかわらず，これまでこれを対象とした研究は見 当たらない社10)。前章で指摘した既往の図式解法の問題 点を解決するためにも，このような群衆の行動特性を考 慮することが不可欠である。EB モデルはこのような要 請に基づいて考案された。ここではその基本的な考え方 とモデル組み立ての理論式を示し, さらにこれを図一 2 の例題に適用して集団の拡散を反映した場合の解析結果 を示し，指針法・PM 法の結果と比較する。

\section{$3.1 \mathrm{~EB}$ モデルの概要注11)}

集団を進行方向に任意の区間に等分し，その一つ一つ をブロックと呼ぶ。各ブロックにおいて, その先頭は自 由歩行速度 $v_{m x}$ で進行し，末尾は当該ブロックの密度 をもとに（1）式によって定めた速度で進行するものと する。ただしブロック先頭は先行ブロックに重なること 
がなく, 各ブロックの密度は最大群衆密度 $\rho_{m x}$ を超えな いものとする。

各ブロックの進行は第 1 (先頭) ブロックから始め, 順次第 2 以降のブロックを進行させる。単位時間におい て, 各ブロックの先頭は先行ブロックに重ならない限り $v_{m x}$ で進行するが, その末尾は自己の密度に応じた速度 となるため, ブロック先頭より速度が低くなり, その結 果ブロックの長さが「伸長」する。また，ネックにおい ても, ブロック先頭はネックの制約を受けずに所定の距 離を進行するが, 後続部分はネックの通過容量の制約を 受ける結果, ブロック末尾の通過が遅れ, ブロックの長 さが伸長する。

前方の障害等で当該ブロックの先頭が停止または速度 低下した場合には, 次の理由によってブロックが「縮小」 する。すなわち, ブロック先頭の進行が停止しても, ブ ロックの密度が $\rho_{m x}$ 末満ならば, 密度が $\rho_{m x}$ に達するま で，ブロック末尾は進行を継続できるからである。

この手続きを単位時間 $d_{t}$ の中で,順次すべてのブロッ クについて行う。すなわち集団は, 先頭から末尾までが $d_{t}$ の間に一斉に歩行する。現実の群衆では, 先行ブロッ クの歩行開始から後続ブロックの歩行開始までの間に, 行動開始までの若干の遅れも考えられるが, ここでは無 視した。同様に, 第 1 ブロックは歩行開始と同時に, 瞬 時に $v_{m x}$ に達することとした。

この $\mathrm{EB}$ モデルの原理は簡単であるため, パソコン でシミュレーションし, 各ブロックの動きが視覚的に表 現できるようにBASIC を用いてプログラミングした。

$3.2 \mathrm{~EB}$ モデルの歩行と停止

（1）理論式 (表-2 参照)

集団の人数を $P$, 長さを $L_{r w}$, 幅員を $W_{r w}$ とし, こ れを $K$ 等分する。各ブロックの人数を $P_{b}$, 長さを $L_{b}$, 第 $i$ 番目のブロック先頭とブロック末尾の位置を, 歩行 開始時の集団末尾の位置からの距離 $D_{t i}, D_{b i}$ でそれぞ れ表す。 $t$ 秒目における位置と単位時間 $d_{t}$ 経過後の位 置を区分する場合には，さらに，それぞれに $p, q$ の添 字をつける。

まずブロック先頭の動きであるが，その進行は次式で 表される。

$$
D_{t i q}=D_{t i \rho}+S_{w t}
$$

ここで $S_{w t}$ はブロック先頭の進行距離で, 次の $S_{w 1}$, $S_{w 2}$ のうち, 小さい方の值である。

$$
\begin{aligned}
& S_{w 1}=v_{m x} d_{t} \cdots \cdots \\
& S_{w 2}=D_{b(i-1) q}-D_{t i \rho}
\end{aligned}
$$

（12）式は自由歩行可能な場合の距離，（13）式は前方 ブロック末尾に重複しないための限界距離である。 次にブロック末尾は次式で表される。

$$
\begin{aligned}
& D_{b i q}=D_{b i p}+S_{w b} \quad\left(L_{b w}>L_{m n}\right) \\
& D_{b i q}=D_{t i p}-L_{m n} \quad\left(L_{b w} \leqq L_{m n}\right)
\end{aligned}
$$

表一2 EB モデルのブロックの進行

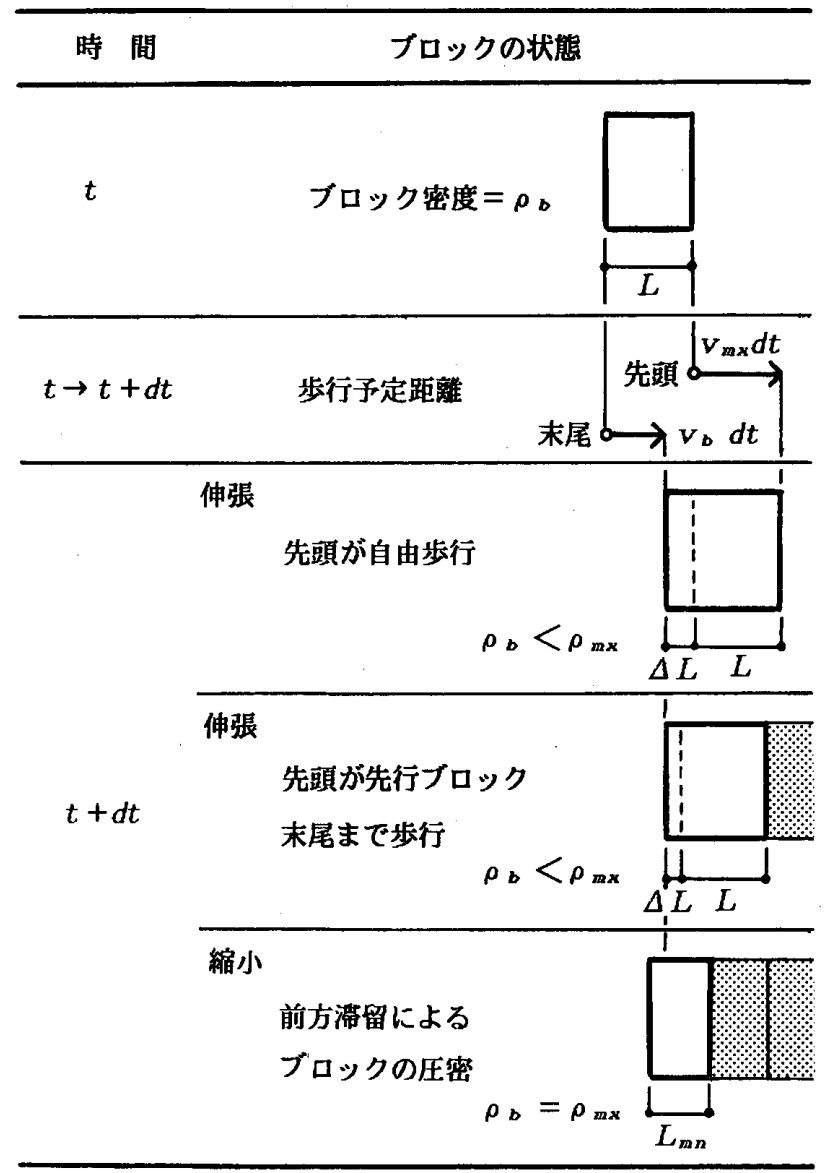

ここで $S_{w b}$ はブロック密度による歩行距離で, ブロッ クの速度を $v_{b}$ (ただし $\left.v_{b} \leqq v_{m x}\right)$, 流動係数を $N$, ブロッ ク密度 $\rho_{b}$ とすると, (1) 式より次式で定める。

$$
S_{w b}=v_{b} d_{t}=\frac{N}{\rho_{b}} d_{t}
$$

(14)，(15）において， $L_{b w}$ は「ブロック末尾が距離 $S_{w b}$ だけ進行できたとした時のブロックの長さ」であり， $L_{m n}$ は「最大密度 $\rho_{m x}$ となった時のブロック長さ」, す なわちブロックのとり得る最短長さである。 $L_{m n}$ は次式 で表される。

$$
L_{m n}=\frac{P_{b}}{\rho_{m x} W_{r w}}
$$

すなわち（14）式は前方に支障がなく歩行できる場合， （15）式はブロック先頭の停止などがあって，ブロック が縮小する場合である。

(2) モデルの動態

上のモデルを図一 2 と同じ集団について解析した。集 団を 20 に分割し，自由歩行速度 $v_{m x}$ を $1.5 \mathrm{~m} / \mathrm{s}, d_{t}$ を 0.05 秒および 0.1 秒とし, 作図は 0.2 秒ごととして各 ブロックの進行状況を表示できるようにした。計算精度 は単精度である。図一5 は通路にネックがなく集団が自 然に拡散してゆく状況を，図一6 は当初の集団末尾位置 から $12 \mathrm{~m}$ の地点で先頭が歩行停止した場合の状況であ る。 


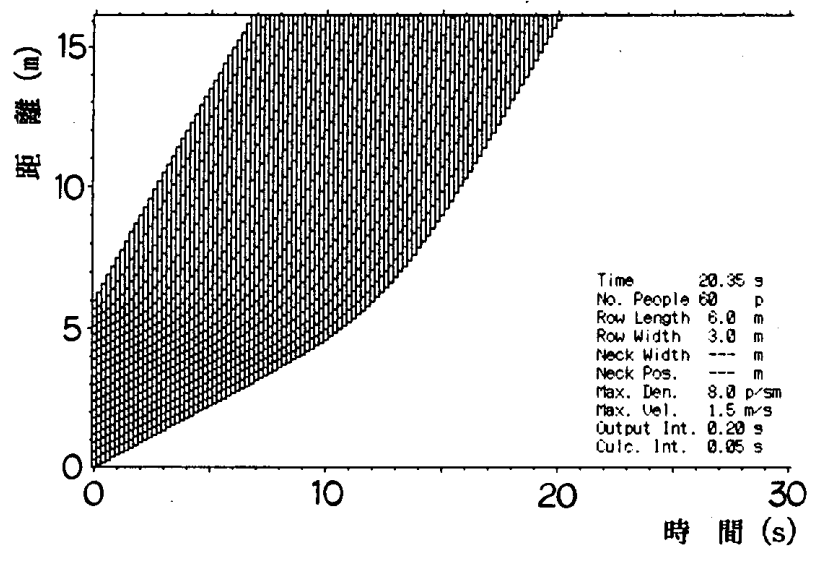

図一5 EB モデルによる集団の自然拡散

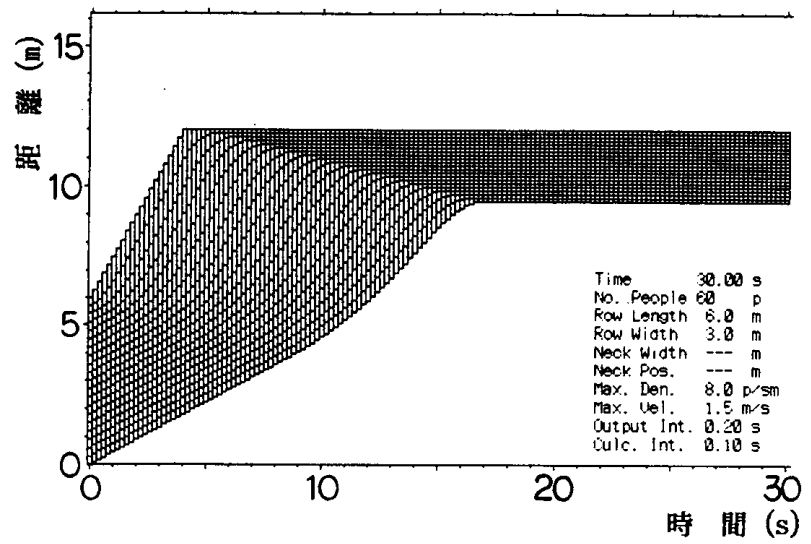

図一6 EB モデルによる集団の停止

図一 5 では集団が徐々に拡散してゆく様子が再現され ている。各ブロックは先頭ブロックから次第にブロック 長さが伸長してゆく。この集団の拡散を, 本モデルの特 性から考察すると, 集団末尾の速度は次第に上昇し, $v_{m x}$ に限りなく近づくはずである。また, 集団全体の密 度は, 先頭の方から徐々に低下し, 全体として 1.5 人 $\mathrm{m}^{2}$ に限りなく近づくはずである。

図一6では先頭の停止による集団の滞留と, 滞留圈の 圧密の様子が再現されている。また, 帯留圏に対する後 続ブロックの接近の様子を見ると, 接近するに従って速 度が徐々に低下しながらブロックが縮小し,あたかも「軟 着陸」のように滞留圏の末尾に加わる, 現実の群衆にお いても観察される様子が再現されている。

滞留圏に停止した集団の全長 $L_{r m n}$ は, 次式で定義で きる。

$$
L_{r m n}=\frac{P}{\rho_{m x} W_{r w}}
$$

例題の集団の場合 $2.5 \mathrm{~m}$ であり, 解析結果とも一致 した。

\subsection{EB モデルのネック通過}

図一7にネックとブロックとの位置関係を示す。この うちネックがAあるいは Dにある場合には, ブロックの 動きはネックがない場合と同じである。したがってネッ ク通過に関しては，ネックがCにある場合（ブロックが

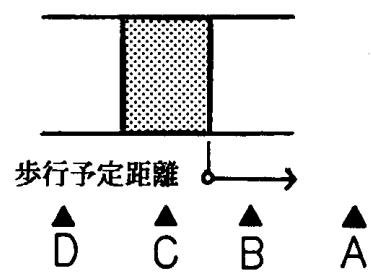

図一7 ブロックとネックの位置関係

ネックを通過中の場合）と， Bにある場合（そのブロッ クが初めてネックを通過する場合）亡が対象となる。

（1）ブロックがネックを通過中の場合

ブロック先頭はネックの制約を受けないので, その進 行については (11)〜 (13) 式を適用して $S_{w t}$ を求める。

ブロック末尾については, 当該ブロックの未通過部分 に対して（14)，(15）式に準じて定める。すなわち，次 式のいずれかとなる。

$$
\begin{array}{ll}
D_{b q}=D_{b p}+S_{w b n} & \left(L_{b w l}>L_{m n l}\right) \\
D_{b q}=D_{n k}-L_{m n l} & \left(L_{b w l} \leqq L_{m n l}\right)
\end{array}
$$

上記 2 式において, $D_{b \rho}, D_{b q}, D_{n k}$ は歩行開始時の集 団末尾からの距離で， $D_{b p}$ は歩行開始より $t$ 秒後におけ るブロック末尾の位置, $D_{b q}$ は $t+d_{t}$ 秒後におけるブ ロック末尾の位置， $D_{n k}$ はネック位置をそれぞれ表す。 $L_{b w l}$ はブロック末尾が $S_{w b n}$ だけ進行できた場合のネッ クから末尾までの長さ， $L_{m n l}$ は (17) 式と同様に, 未 通過部分の人数を $\rho_{m x}$ に圧縮した時の長さである。

（19）式の $S_{w b n}$ は，末通過部分の速度による進行距離 であるが，この速度は単に密度だけから定めることがで きない。戸川によればネック通過時の集団の速度 $v_{a r}$ $\left(v_{a r} \leqq v_{m x}\right)$ は，未通過部分の密度を $\rho_{a r}\left(\rho_{a r} \leqq \rho_{m x}\right)$, 流 動係数を $N$, 通路幅を $W_{r w}$, ネック幅を $W_{n k}$ とすると 次式で表される。また，この関係式は PM 法において も採用されている。

$$
v_{a r}=\frac{N}{\rho_{a r}} \cdot \frac{W_{n k}}{W_{r w}}
$$

したがって， $S_{w b n}$ は次式となる。

$$
S_{w b n}=v_{a r} d_{t}
$$

（20）式は，右辺第 1 項がネック位置となっている点 が（15）式と異なる。

ネックを通過する人数は末通過部分が進行した距離と 密度 $\rho_{a r}$ から求めることができ，これによって，次の単 位時間における残り人数も定めることができる。

（2）ブロックが初めてネックを通過する場合

(11) （13）式より求めた $S_{w t}$ によって， $d_{t}$ 時間後に はブロックがCの状態, すなわちブロックがネックを通 過中の状態になる場合である。前述の仮定によれば，ブ ロック先頭はネックの有無にかかからず所定の距離 $S_{w t}$ を進行できる。ここで, 単位時間 $d_{\imath}$ のうち, ブロック 先頭がネックに到達するまでの時間を $d_{t s}$ とすると, ネック通過があるのは $d_{t}-d_{t s}$ の時間帯であり, $d_{t s}$ の 


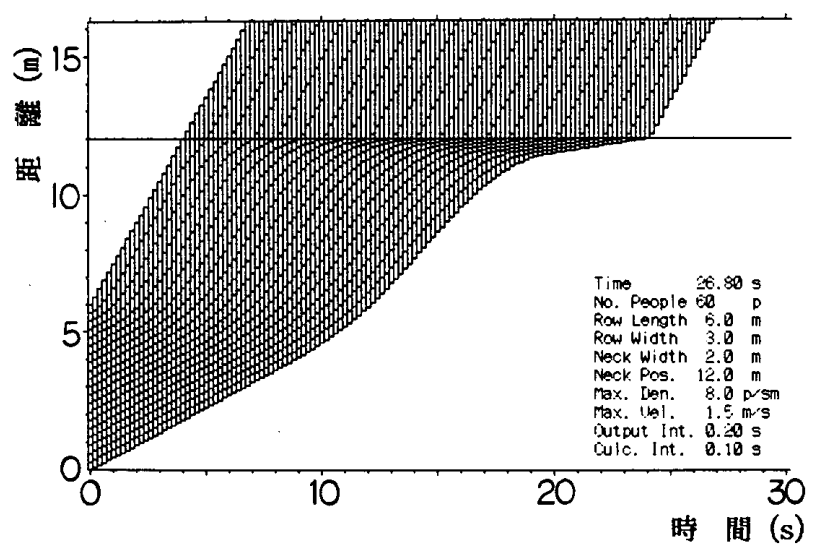

图一8 EB モデルによる例題の解析結果

表一3 EB モデルによる解析結果

\begin{tabular}{|c|c|c|}
\hline 解 析 項 目 & E Bモデル & \\
\hline ネック手前の速度 & 1. $5 \mathrm{~m} / \mathrm{s}$ & (先頭のみ) \\
\hline ネック流出開始 & 4. 0 秒 & \\
\hline ネック流出完了 & 24. 0 秒 & \\
\hline ネック通過所要時間 & 20 . 0 秒 & \\
\hline 最大漟留人数 & 15 & (図より) \\
\hline 最大漟留時刻 & 19 & (図より) \\
\hline ネック通過後の速度 & 1. $5 \mathrm{~m} / \mathrm{s}$ & \\
\hline
\end{tabular}

時間带のネック通過人数は 0 である。

したがって，この場合にはまずブロック全体をネック 位置まで進行させ， $d_{t}-d_{t s}$ 時間について Cの場合と同 じ手続きを行うこととした。

(3) モデルの動態

図一2の例題を $\mathrm{EB}$ モデルを用いて解析した結果を図 -8に示す。

まず, 滞留圏の形成過程を見ると, 帯留圏への到着の 様子が, 図一6で見られたように「軟着陸」であるため, 滞留圈の境界は明確でなく，むしろ後続部分と連続的な 様相を示している。また，本モデルにおける滞留圏の形 成は図一4のグラフ(3のように直線的ではなく，上に凸 の曲線に見える。これは到着集団が非定常であるるすす わち先頭から末尾にかけて徐々に密度が高くなっている ことによるものであろう。

解析結果 (表一3) を見ると, ネックの流出開始時間は, 当然であるが，指針法に等しい。また，ネック通過所要 時間は指針法とPM 法に等しい。最大滞留人数とその 発生時刻は，上記のように帯留圏とそれ以前の部分とが 連続的であるため概略の值を図上より読み取ったが，最 大滞留人数は指針法と PM 法より少ない值となり，そ れが発生する時刻は両者の中間の值であった。

\section{4. まとめ}

以上によって，指針法と PM 法とは本質的には同じ 原理に基づくものでありながら，同一の例題に適用する と結果に大きな差が現れること, その原因は集団の先頭
と末尾との速度差が考慮されていないことを明らかに し，これを解決するには「集団の拡散」を考慮したモデ ルが必要であることを示した。またこのために考案し た $\mathrm{EB}$ モデルの組み立てについて述べ，これによる解 析結果を示し，前 2 者と比較した。

この解析結果の妥当性については, 実測値との比較を 行っていないため, 検証することはできないが, 群采の 行動特性に関するこれまでの定性的な研究結果をよく反

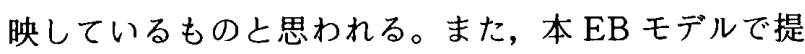
案した理論は,これまで提起してきた群衆流解析の問題 を解決する上で不可欠であると考える。

$\mathrm{EB}$ モデルは，指針法あるいは PM 法のような図式 解法ではなく、コンピュータを使用する必要があり、こ の点では簡便な解法とは言い難い面がある。しかし，こ れまでのコンピュータによる群衆流の解析モデルに比較 すればはるかに簡便であると考える。

本報告の範囲では, $\mathrm{EB}$ モデルは避難行動予測にかか わるすべての状況を取り扱えるまでには至っておらず, その特性についても必ずしもすべてを明らかにしてはい ない。また，指針法と PM 法に対しても，それらの間 の矛盾点の指摘にとよ゙まっている。したがって, 今後の 研究の方向には次の二つの側面が考えられる。第 1 には $\mathrm{EB}$ モデルそのものの諸特性を明らかにすること，第 2 には集団の拡散を考慮した場合における群衆流動の特性 あるいは法則を, EB モデルを用いて探究し，これをも とに既存の図式解法を改良, 補正する方法がないかを探 ることである。特に実用的で簡便な方法を見いだすには 第 2 点の研究に期待するところが大である。以上につい ては引き続き報告を行う予定である。

\section{謝 辞}

本研究に当たっては, 早稻田大学理工学部建築学科, 渡辺仁史教授のご指導をいただいた。また，文献 2)，3） は建設省建築研究所三村由夫, 古瀬 敏両氏のご協力に より，手に入れることができた。ここに記して謝意を表 ఫ。

注

1）本文献の原典は 1969 年に刊行されたが,この英訳版（文 献2）が刊行されたのは1978 年である。さらに 1985 年 になって, 建設省の総合技術開発プロジェクト「建築物 の防火設計法の開発」に関連して, 建築研究所において 邦訳（文献 3) された。

2）1981 年より建築確認手続きの一部が改正され，大規模な 建築物は防災計画書の作成が義務付けられた。防災計画 書は日本建築センターに設置された建築防災計画評定委 員会で審查を受ける。防災計画書には避難計算が必要で あるため, 避難計算を行った物件の数はこの委員会にお ける延べ評定件数より推定できる。1989 年 7 月現在の延 べ評定件数は約 1,700 であるが, 本報でいう指針法が採 用されるようになったのはおおむね 1985 年 8 月以降であ 
り、それまでの 530 件を除外した。

3) 文献 6)による。

4）人が密度の束縛を受けずに自由に歩行する速度で，ここ ではこれを事実上の最高速度と考え記号を $v_{m x}$ とした。

5) Predtechenskii らは文献 2)で「密度の漸次的変化を考 慮する必要がある」とし, 密度の低い集団の後に密度の 高い集団が接して歩行する時, その境界では「遅い部分 から人々が抜け出し，速い部分の速度に同調する。この 過程が綝り返され，次第に速い部分の長さが増える。こ のため密度の高い部分が遅れ, 密度の低い部分にとり残 されることはない」としている。このような指摘にもか かわらず，これが PM 法に反映されていないのは，指針 法で速度と密度の関係を省略したのと同様に, 計算手続 きの簡略化のためであると思われる。PM 法は先頭の速 度の高い部分を無視し，これ以外の部分，すなわち定常 部分のみを対象に解析したものであるといえる。

一方, 戸川の文献 6）によれば, 群衆流には不定常部, 定常部，減衰部があるとしているが，これは到着時間分 布の異なる複数の集団が合流することによってできるも のであり、このことは戸川が不定常部を集結群衆と呼ん でいることでも明らかである。合流以前の個々の集団の 性質までは言及していないが, 戸川も基本的には定常流 のみを取り扱っていると判断される。

6）第 1 の問題による誤差と第 2 の問題による誤差の, ビち らが大であるかは，一概には決められない。例えば， $\rho_{m x}$ が大であれば滞留圏の面積が小さくなるため, 第 2 の誤 差は小さくなる。また, 当初の集団密度が小さいほぼ, 先頭と末尾の速度差が少なくなるので，第 1 の誤差は小 さくなる。このほかに， $v_{\pi x}$ も関連すると思われるが， 例題の場合には前者による誤差の方が大きいといえよう。

7）青梅市役所広報課への取材による。

8）神忠久も文献 8）で青梅マラソンを研究対象に取り上げ, 調查した結果を報告している。ただし，末尾走者の通過 までに時間がかかる原因は，衝突防止のために前後間隔 を大きく取り，「走者の密度をかなり低くしてある」ため としている。

9）例えば東京消防庁消防学校でも，整列した集団が歩行開 始する時の拡散に悩んでおり，この対策として先頭歩行
者に速度を抑制するよう指示しているとのことである。

10）中祐一郎らが文献 9）の中で扱った事例があるが，これ は簡単なもので, 集団の拡散の解析を目的としたもので はないと考える。

11）本モデルについてはすでに文献4）でその概要を報告し たが, その後の検討により，ブロック進行の仕組みがよ り単純化できることが判明した。このため, 本報と文献 4) とでは考え方にやや相違点が出た。

\section{参考文献}

1）建設省住宅局建築指導課監修：新・建築防災計画指針 1985 年版, 日本建築センター, pp. 123 153, 1985

2) V.M. Predtechenskii, A. I. Milinskii : Planning for Foot Traffic Flow in Buildings, [Proektirovanie Zhdaniis Uchetom Organizatsii Ovizheniya Lyudskikh Potokov, Straiizdat Publishers, 1969], Translated from Russian Amerind Publishing Co. Pvt. Ltd., 1978

3）香川正弘訳：建物内の歩行流についての計画, 部外研究 員研究報告書, 建築物火災時の避難性状予測に関する研 究, 建設省建築研究所第 5 研究部, 1985

4）吉田克之, 上原茂男 : 防災計画の研究，5. 伸縮ブロック モデルによる群衆流の解析, 日本建築学会大会学術講演 梗概集 (熊本), pp. 773 774, 1989

5) 吉田克之, 浜田 啓: 防災計画の研究, 2.グラフモデル による避難シミュレーション法の提案, 日本建築学会大 会学術講演梗概集, pp. $877 \sim 878,1976$

6）戸川喜久二：群衆流の観測に基づく避難施設の研究, 学 位論文, 1963

7) Ezel Kendik : Determination of the Evacuation Time Pertinent to the Projected Area Factor in the Event of Total Evacuation of High-rise Office Buildings via Staircases, Fire Safety Journal, 5, 1983, pp. 223 232

8）神忠久：群衆の種類と歩行速度について, 火炎 142 , Vol. 33, No. 1, pp. 8 12, 日本火災学会, 1983.2

9）坂井義生, 上原孝雄, 中祐一郎：群集流動の基本型シミュ レーション(その 2 ) 日本建築学会大会学術講演梗概集 (東 北), pp. $499 \sim 500,1973$ 


\section{SYNOPSIS}

UDC : 614.88

PROBLEMS OF CONVENTIONAL GRAPHIC METHODS IN ESCAPE FLOW ANALYSIS AND A PROPOSAL OF ELASTIC BLOCK MODEL

Human flow analysis by Elastic Block Model : Part I

by YOSHIYUKI YOSHIDA Manager, Building Design Department of Takenaka Corporation, Member of A. I. J.

Today, many Japanese architects and engineers use graphic-analytical method, provided by Building Center of Japan to evaluate their plans for safety escaping. There was also another graphic-analytical method which was established by Predtechenskii and Milinskii in USSR by 1969. However, these methods do not reflect enough characteristics in human traffic flow. The purpose of this study is to clarify the problems of these conventional methods, and to propose a new method. This is Part I of a series of study, reporting following contents ;

(1) Discovery of large deferences when the two methods were applied in a same situation.

(2) Pointing out as follows;

a. Cause for the deferences came from not considering the deference of speeds between top and bottom of the traffic mass.

b. Necessity for a model which can reflect spread of human mass in process, based on correlationship between density and velocity of a human traffic flow.

(3) Explanation of Elastic Block Model logic.

(4) Application of E. B Model to the same situation. 